\title{
Calculating Linear and Areal and Relief Aspect Parameters Using Geo-Spatial Techniques (ArcGIS 10.2 and SWAT model) for Akkeru River Basin Warangal, Telangana, India
}

\author{
Jatoth Veeranna ${ }^{1 *}$, Konda Gouthami ${ }^{2}$, Perugu Balachandra $\operatorname{Yadav}^{1}$ and \\ V.R. Mallikarjuna ${ }^{2}$ \\ ${ }^{1}$ Division of Agricultural Engineering, ICAR-Indian Agricultural Research Institute, \\ New Delhi-12, India \\ ${ }^{2}$ Agricultural Engineering, Indira Gandhi Krishi Vishwavidyalaya, Raipur, Chhattisgarh, India \\ *Corresponding author
}

\section{A B S T R A C T}

Keywords

Linear, Areal and relief aspect, Akkeru River Basin.

Article Info

Accepted:

17 September 2017

Available Online:

10 October 2017
The advent of geographic information system techniques (GIS) allowed users for the quantitative characterization of landforms with great speed and precision. An attempt was made to evaluate the linear, areal and relief aspects of the Akeru river basin of Warangal district in Arc-GIS 10.2 platform. Hence, from the present study, it concluded that remote sensing techniques (ASTER-DEM) coupled with GIS can be a powerful tool in morphometric analysis of a region or basin and the data can be used for hydrological studies and water resource management. In the present study the liner and areal aspect parameters were calculated. The major parameters were Drainage density, stream order and Bifurcation ratio were play major role for hydrological processing and the values were, $0.58,1-5^{\text {th }}$ order and 4 respectively.

\section{Introduction}

Morphometric is the measurement and mathematical analysis of the configuration of the earth's surface, shape and dimension of its landforms (Agarwal 1998; Hajam and Hamid et al., 2013). Morphometric analysis of basin in hydrology was first initiated by Horton (1945) and Strahler (1968). This mainly includes linear aspects, areal aspects and relief aspects of a basin. Morphometric analysis of a drainage basin represents the state of dynamic balance that has been developed due to dealings between matter and energy over a period of time.
The important hydrologic phenomena linked with the physiographic characteristics of drainage basins are size, shape, slope of drainage area, drainage density, size and length of the contributing streams, stream order and drainage pattern etc. (Horton 1945; Leopold and Miller 1956). This analysis is very important for the development of a basin, planning of water harvesting and storage, water resource management and even for evaluating potential zone of groundwater recharge (Sreedevi et al., 2009; Swami and Kulakarni, 2014). It is also important for 
different socio economic studies for sustainable development of an area.

The advent of geographic information system techniques (GIS) allowed users for the quantitative characterization of landforms with great speed and precision. These techniques are now a day are largely being used for assessing various landforms and morphometric parameters of the basins, as it provide a flexibility and several geospatial tools for manipulation and interpretation of data (Mark 1983). Morphometric analysis of a region provides a quantitative description of the drainage pattern of a region, which is an important aspect for management of basins (Magesh et al., 2013; Khanday and Javed 2016). The present study deals with the process of evaluation of various morphological parameter of river basin of Akeru, Warangal district, Telangana, India using ArcGIS 10.2 software for the development and management of natural resources of the region.

\section{Materials and Methods}

\section{Study area}

Warangal district is located in the northern region of the state of Telangana, on the southern part of India the total geographical area and perimeter of Akeru river basin Warangal district is 12096.45 square kilo meters and 822.16 kilo meters respectively. The study area is located at 18.14'58" N latitude and 79.58'84" E longitude with an average elevation is about $302 \mathrm{~m}$ above mean sea level (Fig. 1). The District have major and minor irrigation projects area under around five reservoirs and lakes viz; Ramappa lake. Besides, whole district is divided into 5 Taluka (revenue divisions) namely Warangal, Jangaon, Mulugu, Narsampet and Mahbubabad. The average high temperature is about $42{ }^{\circ} \mathrm{C}\left(108{ }^{\circ} \mathrm{F}\right)$ reaches in May whereas during winter average temperatures and rainfall is about $22-23{ }^{\circ} \mathrm{C}$ and $950 \mathrm{~mm}$ respectively.

The different morphometric parameters were calculated to quantify linear, areal and relief aspects of study area. The all formulae with their dimensions and the outputs are presented in Table 1. The morphometric parameters of Akeru river basin were analysed.

\section{Linear aspects}

A linear aspect of morphometric analysis of a region includes stream order, stream length, mean stream length, stream length ratio, and Bifurcation ratio.

\section{$\operatorname{Basin} \operatorname{area}\left(A_{b}\right)$}

The area of basin is an important factor for any watershed. The relationship between total area and total stream length reported by Schumm (1956).

\section{Stream order $\left(\mathbf{N}_{\mathrm{u}}\right)$}

The stream order is defined as the determination of hierarchical position of stream with a drainage basin. The highest order stream knows as trunk stream. Using the Strahler (1968) morphometric analysis of Warangal district the trunk stream order was found fifth order.

\section{Stream length (Lu)}

The stream length is represented by its total length of streams of a specific order. The property of drainage network of region and is measured from mouth of stream to drainage divide. The total stream length with stream order relation was found with help of ArcMap 10.2 software (Table 1).

$$
y=-910.33 U+4238.3
$$


Where,

$\mathrm{Y}=$ stream length of order $\mathrm{U}, \mathrm{km}$

\section{Stream numbers $(\mathbf{N})$}

The stream number is the number of streams having of various orders and it is inversely proportion to the stream order. The relationship is represented by the following regression equation between two parameters with $\mathrm{R}^{2}$ value of 0.99 (Singh et al., 2016).

$N u=3815.3 e^{-0.671 U}$

Where,

$\mathrm{Nu}=$ Number of streams of order $\mathrm{U}$.

\section{Bifurcation ratio $\left(\mathbf{R}_{\mathbf{b}}\right)$}

It is defined as the number of streams of a particular order to the number of streams of a next lowest order (Table 1).

\section{Areal aspects}

This analysis includes the drainage density, stream frequency, texture ration, form factors, circulatory ratio, length of over land flow and constant of channel maintenance. This analysis is very useful for deriving the relationship between stream discharge and area of basin.

\section{Drainage density}

It is the ratio of total length of stream to its total drainage area. It is important factor for indication of landscape dissection and peak runoff potential of basin. The drainage density pattern as follows: Course if $D_{D}$ $=\leq 5 \mathrm{~km} / \mathrm{km}^{2} ; \quad$ Medium if $\mathrm{D}_{\mathrm{D}}=5-10 \mathrm{~km} / \mathrm{km}^{2} ;$ and Fine if $D_{\mathrm{D}}=\geq 10 \mathrm{~km} / \mathrm{km}^{2}$. The present study area the drainage density was calculated with help of ArcGIS 10.2 software.

\section{Stream frequency $\left(\mathrm{N}_{\mathrm{F}}\right)$}

The stream frequency also called as drainage frequency. It is calculated by dividing the total number of streams to total area (Horton 1932). It is mainly depends on rainfall and physiography of the region.

\section{Form factor $\left(F_{F}\right)$}

It is the ratio of basin area to square of maximum basin length. It is mainly represent the shape of basin. The form factor mainly used for representing the basin shape and it is a dimensionless number.

\section{Circulatory ratio $\left(\mathbf{C}_{\mathrm{R}}\right)$}

The circulatory ratio also called as hydraulic radius. It is useful for measuring basin shape and varies from zero for elongated and one for circular basin.

\section{Elongation ratio $\left(\mathbf{E}_{\mathbf{R}}\right)$}

Elongation ratio is defined as the ratio of the diameter of a circle having the same area as the basin and the maximum basin length (Schumn1956)

\section{Compactness coefficient or Compactness constant $\left(\mathbf{C}_{\mathbf{C}}\right)$}

The compactness constant defined as the ratio of the perimeter of the catchment to its perimeter of the circle whose area is that of the basin. It is depend mainly on the slope and independent on size of watershed.

\section{Length of over land flow or extension of the surface route $\left(\mathrm{L}_{\mathrm{OLF}}\right)$}

The overland flow is the first mechanism of surface flow and it is describes as length of flow path over the ground before its gets concentrated into a particular stream network and it is dominated in small watersheds only. 


\section{Constant of channel maintenance $\left(\mathrm{C}_{\mathrm{CM}}\right)$}

It is the reciprocal of drainage density and having units of basin length (Schumm 1956). The constant implies the number of $\mathrm{km}^{2}$ of basin surface required to develop and sustain a channel $1 \mathrm{~km}$ long.

\section{Relief aspects}

The relief aspects includes relief, relief ratio and ruggedness number for a selected basin

\section{Relief ratio $\left(\mathbf{R}_{\mathbf{R}}\right)$}

It is the ratio of the total relief of the basin to it the longest basin length measured along the main drainage line (Schumm 1956). The low value of relief is due to hard rock and low degree of slope. The highest value indicates steep slope and high relief.

\section{Ruggedness number $\left(\mathbf{R}_{\mathrm{N}}\right)$}

The product of drainage density and basin relief (Stahhler, 1968). This analysis is very useful for steepness and slope of the drainage network.

\section{Results and Discussion}

In the present study, the basin perimeter and area were calculated with help of ArcGIS and value was $822.16 \mathrm{~km}$ and $12096.45 \mathrm{~km}^{2}$ respectively. The stram order using the Strahler (1964) morphometric analysis of akkeru river basin, the trunk stream order was found of fifth order. The total number of streams of 1 to $5^{\text {th }}$ order obtained for Akeru river basin has presented in (Table 1) was calculated with help of ArcGIS 10.2. The total stream length was found as $7536.5 \mathrm{~km}$ with help of ArcMap 10.2 software (Table 1). The first order stream length was found (3914.5), second order (2074.8), third order (924.4), fourth order (445.0) and fifth order (177.7) as shown in (Table 1). The stream number was obtained as 3792; the stream number of watershed having maximum numbers of first order $(\mathrm{Nu}=2018)$ followed by second $(\mathrm{Nu}=$ $985)$, third $(\mathrm{Nu}=448)$, fourth $(\mathrm{Nu}=210)$ and fifth $(\mathrm{Nu}=131)$ order respectively (Table 1$)$. The above relation speaks that the stream order is increases with decreasing stream frequency. The variation and relationship between the stream order, stream length and stream number (Figs. 2 and 3). The relationship is represented by the following regression equation between two parameters with $\mathrm{R}^{2}$ value of 0.99 (Singh et al., 2016).

$N u=3815.3 e^{-0.671 U}$

Where,

$\mathrm{Nu}=$ Number of streams of order $\mathrm{U}$.

The value of the bifurcation ratio was obtained as 4 and values typically lie in the range 3-5 (Strahler 1964). The calculation procedure of bifurcation ratio of study area is given in Table 1.

\section{Areal aspects}

This analysis includes the drainage density, stream frequency, texture ration, form factors, circulatory ratio, length of over land flow and constant of channel maintenance. This analysis is very useful for deriving the relationship between stream discharge and area of basin.

\section{Drainage density}

The drainage density was found 0.58 (Table 1). The larger drainage density results peak runoff and quick disposal of runoff to downwards channel. As results the small base time with high peak hydrograph will be forms and less time for infiltration of water into soil. This will forms mainly due to lack of 
watershed management, urbanization, lower land use land cover and vegetation growth. The value was 0.58 and value shows that the watershed has courser drainage density. However, concentration of soil erosion would be depends on the development stages of drainage lines in the watersheds.

The stream frequency also called as drainage frequency. The stream frequency relates to permeability, infiltration capacity and relief of watershed. It was found 0.31 (Table 1), shows the positive correlation and increases with respect to the drainage density. The form factor mainly used for representing the basin shape and it is a dimensionless number. For an elongated basin it tends to zero, for a circular it is not exceed 0.75 and, perfect square basin is reaches to one (Horton 1932). The form factor was 0.42 (Table 1) indicating that the watershed was less elongated in shape. The circulatory ratio $\left(C_{R}\right)$ is useful for measuring basin shape and varies from zero for elongated and one for circular basin. The value was obtained 0.42 (Table 1) and it is generally varies 0.4 to 0.5 (Miller, 1953).

Fig.1 Study area with district Thalukas/headquarters
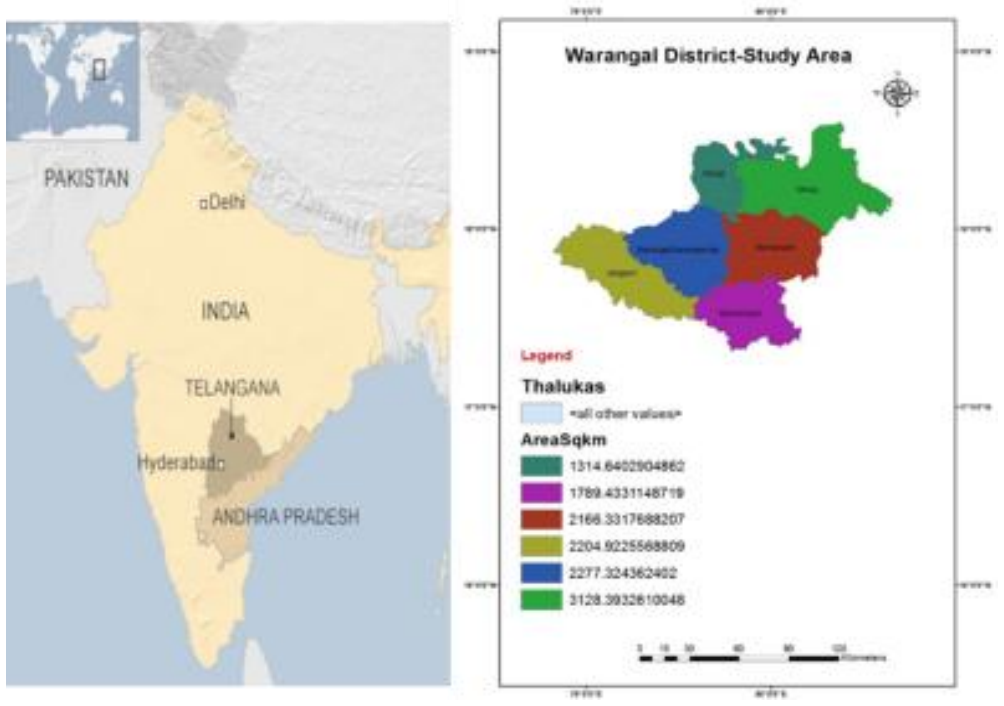

Fig.2 Stream length with stream order of Akeru river basin

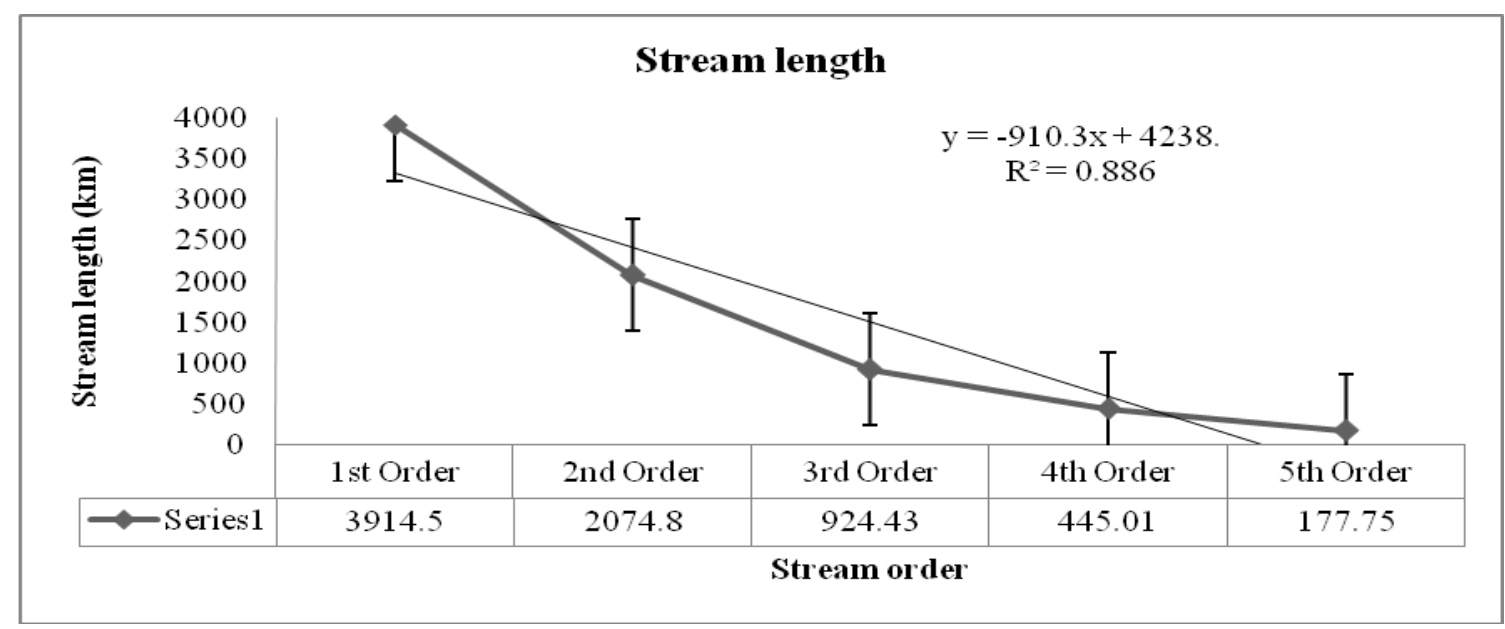


Fig.3 Relationship between stream numbers with stream order of Akeru river basin

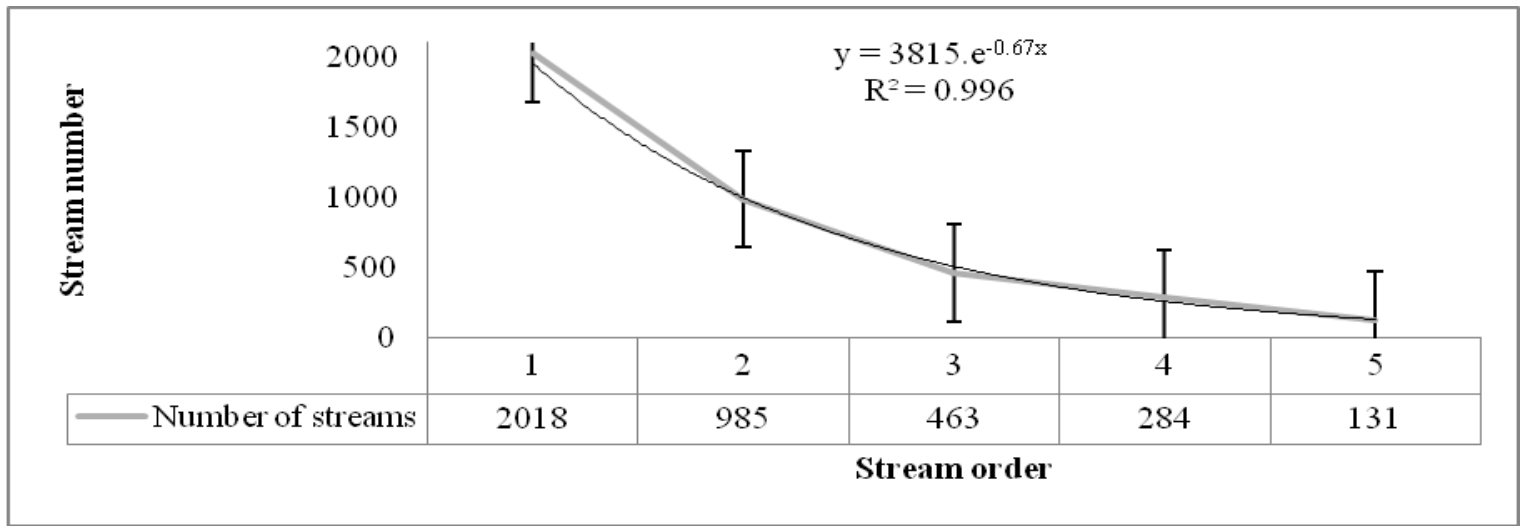

Table.1 Linear, Areal and relief aspect parameters of Akeru river basin, Warangal study area

\begin{tabular}{|l|l|l|}
\hline S. No & Parameter & Output \\
\hline & Linear Aspect & 5 \\
\hline 2 & Stream order & 7536.5 \\
\hline 3 & Stream length & 3792 \\
\hline 4 & Streams number & 4 \\
\hline 5 & Bifurcation Ratio & \multicolumn{2}{|l|}{} \\
\hline & Areal Aspects & 0.58 \\
\hline 1 & Drainage Density & 0.31 \\
\hline 2 & Stream frequency & 0.42 \\
\hline 3 & Form factor & 0.22 \\
\hline 4 & Circulatory ratio & 0.62 \\
\hline 5 & Elongation ratio & 2.11 \\
\hline 6 & Compactness coefficient & 0.86 \\
\hline 7 & Length of overland flow & 1.61 \\
\hline 8 & Constant of channel maintenance & \\
\hline & Relief Aspects & 0.93 \\
\hline 1 & Relief ratio & 0.44 \\
\hline 2 & Relative relief & 227.41 \\
\hline 3 & Ruggedness number & \multicolumn{2}{|l|}{} \\
\hline
\end{tabular}

The value of elongation ratio generally varies from 0.6 to 1.0 over a wide variety of climatic and stream geologic conditions. In the present study the value found as 0.62 . The compactness constant was calculated value 2.11 of compactness coefficient (Table 1). The overland flow was observed in the basin is $0.86 \mathrm{~km}$ (Table 1) which represent that the watershed has low surface runoff The high value of length of overland flow represent lower drainage density. The high value of constant of channel maintenance $\left(\mathrm{C}_{\mathrm{CM}}\right)$ represent lower drainage density and the value of watershed was found 1.61 (Table 1).

\section{Relief aspects}

The relief was observed $365 \mathrm{~m}$ (Table 1) and the study area mean sea level was observed as $140 \mathrm{~m}$. The relief ratio $\left(R_{R}\right)$ was observes that 0.93 (Table 1) and the low value of relief due to hard rock and low degree of slope. The 
Ruggedness Number $\left(R_{n}\right)$ value was observed 227.41 (Table 1). This analysis reveals that GIS is an effective tool for analysis of morphometric parameters of the basin. The Warangal district having stream order from 1 to 5 and dominated by mainly lower order streams. The circulatory ratio was found 0.42 which represent the feature of elongated basin. The $\mathrm{D}_{\mathrm{d}}$ was found 0.58 which indicates high runoff potential. Morphometric analysis employed in this study will assist planner and policy makers for development and management of natural resource under changing climate scenario.

\section{References}

Agarwal, C.S., 1998. Study of drainage pattern through aerial data in Naugarh area of Varanasi district UP. Journal of the Indian Society of Remote Sensing, 26(4), 169-175.

Hajam, R.A., Hamid A, Bhat S (2013) Application of morphometric analysis for geohydrological studies using geo-spatial technology a case study of Vishav Drainage Basin. Hydrology: Current Research. 4(3), 112.

Horton, R.E., 1932. Drainage- basin characteristics. Eos, Transactions American Geophysical Union, 13(1), 350-361.

Horton, R.E., 1945. Erosional Development of streams and their drainage basins, Hydrological approach to quantitative morphology. Geological Society of American Bulletin 56, 275-370.

Khanday, M.Y., Javed A 2016. Impact of climate change on land use/land cover in Chopan Watershed, Guna District (MP), using remote sensing and GIS. J Environ Res Dev 2(4):568-579

Leopold, L.B., Miller JP, 1956. Ephemeral streams; hydraulic factors and their relation to the drainage net U.S. Geological Survey Professional Paper No. 282-A.

Magesh, N.S., Jitheshlal KV, Chandrasekar N, Jini KV 2013. Geographical information system-based morphometric analysis of Bharathapuzha river basin, Kerala, India. Applied Water Science, 3(2), 467-477.

Mark, D.M., 1983. Relation between fieldsurveyed channel network and map-based geomorphometric measures, Inez Kentucky. Ann Assoc Am Geogr 73(3):358-372

Schumm, S.A., 1956. Evolution of drainage systems and slopes in badlands at Perth Amboy, New Jersey. Geological society of America bulletin, 67(5), 597-646.

Singh, S., Bhardwaj A, Verma VK 2016. Hydrological Characterization of Dholbaha Watershed in Shivalik Foothills using RS and GIS. Journal of Agricultural Engineering, 53(2), 1-11.

Sreedevi, P.D., Owais S, Khan HH, Ahmad S 2009. Morphometric analysis of a watershed of South India, Using SRTM and GIS data. J GeolSoc India 73:543-552

Strahler, A.N., 1964. Quantitative geomorphology of drainage basin and channel networks. In: Chow VT (Ed.). Handbook of applied hydrology. New York: McGraw Hill Book Company, 4-11.

Strahler, A.N., 1968. Quantitative geomorphology: In: Fairbridge RW 9(Ed.) Encyclopedia of geomorphology. Reinhold Book crop, New Yark.

Swami Vidula, A., Kulkarni Sushma S 2014. Evaluation of the Best Management Practices Using SWAT Model for the Kaneri MicroWatershed, Southern Maharashtra, India. International Journal of Advanced Technology in Engineering and Science, 2, 916.

\section{How to cite this article:}

Jatoth Veeranna, Konda Gouthami, Perugu Balachandra Yadav and Mallikarjuna, V.R. 2017. Calculating Linear and Areal and Relief Aspect Parameters Using Geo-Spatial Techniques (ArcGIS 10.2 and SWAT model) for Akkeru River Basin Warangal, Telangana, India. Int.J.Curr.Microbiol.App.Sci. 6(10): 1803-1809. doi: https://doi.org/10.20546/ijcmas.2017.610.217 